\title{
Vagal nerve stimulator masquerading as an inhaled foreign body in a child
}

\author{
Ayeshah Abdul-Hamid, Samuel MacKeith
}

Otolaryngology, Oxford University Hospitals NHS Foundation Trust, Oxford, UK

Correspondence to Ayeshah Abdul-Hamid, ayeshah89@hotmail.com

Accepted 12 April 2017

\section{Q Crossark}

To cite: Abdul-Hamid A, MacKeith S. BMJ Case Rep Published Online First: [please include Day Month Year]. doi:10.1136/bcr-2017220157

\section{DESCRIPTION}

An 8-year-old girl with a history of cyclin-dependent kinase-like 5 (CDKL5) disorder was presented to the emergency department with a short history of stridor and intermittent respiratory distress following eating a biscuit. She had a background of CDKL5 disorder causing neurodevelopmental delay, including being non-verbal, and refractory epilepsy for which she had received a vagal nerve stimulator (VNS) implanted 2 years prior. On initial examination she was noted to be maintaining her oxygen saturations but with intermittent worsening of her stridor and a barking cough. There was no clear preceding history of an upper respiratory tract infection. Given the concerns regarding a potential inhaled foreign body and only minor improvement with steroids and nebulised adrenaline, she was transferred to theatre for formal microlaryngobronchoscopy.

Microlaryngobronchoscopy confirmed oedema of the glottis (figure 1) and subglottis but no inhaled foreign body. It was noted that there was intermittent laryngospasm affecting the left vocal cord (VC) only. During the procedure it became apparent that the left VC was maximally adducting for $20 \mathrm{~s}$ every $40 \mathrm{~s}$ (Video 1). The patient's mother confirmed that the VNS was set to activate every minute. This knowledge in combination with the timing of the examination findings led to the conclusion that this acute presentation was due to mild croup

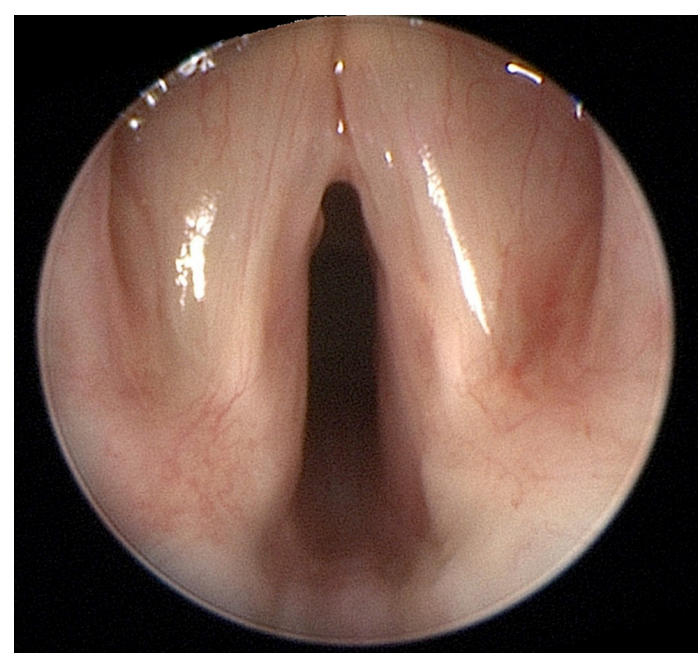

Figure 1 Intraoperative image showing oedema of the vocal cords. in combination with previously undetected left laryngeal hemispasm as a result of the VNS. She was managed for croup and her stridor, resolved without altering the settings of the VNS, allowing her to be discharged home after 48 hours.

VNS is a surgically implantable device used for the treatment of medically refractory epilepsy. VNS is rarely encountered by otolaryngologists; however, stimulus-related laryngopharyngeal side effects of VNS, such as periodic dysphonia, dysphagia and coughing, are not uncommon. ${ }^{1}$ At high stimulation amplitude, spastic contractions of ipsilateral intrinsic laryngeal muscles can be observed at laryngoscopy. ${ }^{1}$ Stridor has also been reported in a small number of cases; one patient had sleep-related stridor, and others had episodic stridor. ${ }^{23}$ In all cases once the VNS settings were decreased, the stridor resolved.

This case highlights the difficulty in detecting the side effects in VNS especially in children with neurodevelopmental delay.

\section{Learning points}

- Vagal nerve stimulators (VNS) can cause laryngopharyngeal side effects including stridor.

- Awareness of the potential for laryngopharyngeal dysfunction with VNS is important especially in young children and in patients who may be difficult to assess.

- A careful history is key in the assessment of a child being presented with stridor.

Contributors AA-H: Obtained patient consent, wrote the article and submitted it for review. SM: Reviewed and edited the final article and selected the best image.

Competing interests None declared.

Patient consent Consent obtained from guardian.

Provenance and peer review Not commissioned; externally peer reviewed.

(c) BMJ Publishing Group Ltd (unless otherwise stated in the text of the article) 2017. All rights reserved. No commercial use is permitted unless otherwise expressly granted.

\section{REFERENCES}

1 Kersing W, Dejonckere PH, van der Aa HE, et al. Laryngeal and vocal changes during vagus nerve stimulation in epileptic patients. J Voice 2002;16:251-7.

2 Kelts G, O'Connor PD, Hussey RW, et al. An electrical cause of stridor: pediatric vagal nerve stimulators. Int J Pediatr Otorhinolaryngol 2015;79:251-3.

3 St Louis EK, Faber K. Reversible sleep-related stridor during vagus nerve stimulation. Epileptic Disord 2010;12:76-80. 
Copyright 2017 BMJ Publishing Group. All rights reserved. For permission to reuse any of this content visit http://group.bmj.com/group/rights-licensing/permissions.

BMJ Case Report Fellows may re-use this article for personal use and teaching without any further permission.

Become a Fellow of BMJ Case Reports today and you can:

- Submit as many cases as you like

- Enjoy fast sympathetic peer review and rapid publication of accepted articles

Access all the published articles

- Re-use any of the published material for personal use and teaching without further permission

For information on Institutional Fellowships contact consortiasales@bmjgroup.com

Visit casereports.bmj.com for more articles like this and to become a Fellow 